\title{
Cultivation of taioba in hydroponic system (ebb and flow) using different substrates
}

Cultivo de taioba em sistema hidropônico ( $e b b$ and flow) empregando diferentes substratos

\author{
A. Costa ${ }^{1}$; E. C. da Silva ${ }^{2 *}$; L. A. Carlos ${ }^{1}$; L. M. Martins ${ }^{2}$; G. M. Maciel ${ }^{3}$; T. F. \\ N. de Mendonça ${ }^{3}$ \\ ${ }^{1}$ Departamento de Engenharia de Alimentos, Laboratório de Tecnologias de Frutas e Hortaliças, Universidade \\ Federal de São João del-Rei, Campus Sete Lagoas, 35701-970, Sete Lagoas-MG, Brasil
}

${ }^{2}$ Departamento de Ciências Agrárias, Laboratório de Campo de Hidroponia de Hortaliças de Folhas, Hortaliças de Frutos e Nutrição Mineral de Plantas, Universidade Federal de São João del-Rei, Campus Sete Lagoas, 35701-970, Sete Lagoas-MG, Brasil

${ }^{3}$ Instituto de Ciências Agrárias, Departamento de Melhoramento Genético Vegetal e Sementes, Universidade Federal de Uberlândia, Campus Monte Carmelo, 38500-000, Monte Carmelo-MG, Brasil

*clarete@ufsj.edu.br

(Recebido em 11 de janeiro de 2019; aceito em 30 de junho de 2020)

\begin{abstract}
Taioba is a plant species from the group of unconventional vegetables that has currently been introduced into the Brazilian diet. The objective of the present work was to study the technical feasibility of the cultivation of taioba in the hydroponic ebb and flow system and the influence of the substrate. The experimental design was in randomized blocks and the treatments consisted of 10 different substrates: (1) $60 \%$ sand $+40 \%$ coal powder; (2) $80 \%$ coconut fiber $+20 \%$ vermiculite vermiculite; (3) $80 \%$ Sand $+20 \%$ coal powder; (4) $70 \%$ sand $+30 \%$ humus; (5) coconut fiber; (6) $70 \%$ sand $+30 \%$ vermiculite; (7) $80 \%$ sand $+20 \%$ vermiculite; (8) sand; (9) commercial substrate Carolina ${ }^{\circledR}$ and (10) $50 \%$ sand $+30 \%$ humus + $20 \%$ vermiculite. The best results were obtained with treatments 2 and 9 for the number of leaves, plant height, stem diameter, transverse and longitudinal leaf diameters, dry and fresh root mass, and dry and fresh plant mass. Except for the total carotenoid contents, no statistical differences were observed for the physical-chemical characteristics. It was concluded that cultivation of taioba in the hydroponic ebb and flow system has technical feasibility. The substrate has influence in the technical feasibility.

Keywords: Xanthosoma sagittifolium, subirrigation, environment.
\end{abstract}

Taioba é uma espécie vegetal do grupo das hortaliças não convencionais que atualmente tem sido introduzida na dieta alimentar do brasileiro. O objetivo do presente trabalho foi estudar a viabilidade técnica do cultivo de taioba no sistema hidropônico $e b b$ and flow e a influência do substrato. O delineamento experimental foi em blocos ao acaso e os tratamentos se constituíram do uso de 10 tipos de substratos: (1) $60 \%$ de areia $+40 \%$ de pó de carvão; (2) $80 \%$ de fibra de coco $+20 \%$ de vermiculita; (3) $80 \%$ de Areia + $20 \%$ de pó de carvão; (4) $70 \%$ de areia $+30 \%$ de húmus; (5) fibra de coco;(6) $70 \%$ de areia $+30 \%$ de vermiculita; (7) $80 \%$ de areia $+20 \%$ de vermiculita; (8) areia; (9) substrato comercial Carolina ${ }^{\circledR}$ e (10) $50 \%$ de areia $+30 \%$ de húmus $+20 \%$ de vermiculita. Observou-se que para número de folhas, altura da planta, diâmetro do caule, diâmetros transversal e longitudinal da folha e massas secas e frescas da raiz e da planta, os melhores resultados foram obtidos com os tratamentos 2 e 9 . Com exceção dos teores de carotenóides totais, não foi observado diferença estatística para as características físico-químicas. Concluiu-se que o cultivo de taioba no sistema hidropônico $e b b$ and flow tem viabilidade técnica. $\mathrm{O}$ substrato tem influência na viabilidade técnica.

Palavras-chave: Xanthosoma sagittifolium, subirrigação, ambientes.

\section{INTRODUCTION}

Xanthosoma sagittifolium (L.) Schott is a hardwood crop originating from South America and its cultivation and consumption come from Central America, Asia and Africa [1]. In Brazil this species is known as taioba [2]. High temperatures, which can be found in the tropical and subtropical regions, are required for taioba development. Its leaves and rhizomes are used for 
human nutrition. Its rhizomes are a source of vitamins $\mathrm{A}$ and $\mathrm{C}$ and also rich in iron, potassium, calcium and manganese [1].

One of the largest obstacles preventing increased production of this crop is related to the scarcity of options as far as the system of cultivation adopted producers. The cultivation is mostly carried out directly in the soil, using its rhizomes. This methodology has limited the expansion of the cultivation area [1]. However, this method makes it difficult to expand the cultivation area since a plant originates a main rhizome and few secondary shoots after six months of cultivation. Thus, seedling production is low with a high volume of material to be transported [1]. Hydroponic cultivation could be an alternative of great potential for taioba production. However, one of the great challenges to cultivate taioba using a hydroponic method is related to the mode of reproduction (vegetative propagation) resulting in the lack of hydroponics utilized in the producing areas.

Alternatively, there are reports of a successful technique called sub-irrigation, which consists of the application of water and nutrients to the bottom of the cultivation pots filled with substrate $[3,4,5]$. The system can use other equipment, being the most common tables of sub-irrigation (ebb-and-flow). The ebb and flow technique was successfully used for the production of salvia (Salvia officinalis L.) [6]. It was also used for the production of arum lily (Zantedeschia aethiopica L. Spreng.) [3] whose structural part of roots and rhizomes are similar to taioba. Ensinas et al. (2011) [7] report that the development of plants confined in a pot with substrate depends on several factors, and its composition is a factor of great importance, since root initiation and rooting are directly linked to the chemical, physical and biological characteristics of the substrate. Environmental conditions, fertilization, genetic factors, degree of maturation, plant variety, among others, have a large influence on the phytochemical content of vegetables [8]. However, studies that correlate cultivation practices with the production of phytochemicals are rather scarce [9]. On the other hand, accord Vence (2008) [10] in addition to sub-irrigation, it is necessary to correctly define the ideal substrate for the best performance of the plant.

Thus, the objective of the present work was to study the technical feasibility of the cultivation of taioba in the hydroponic ebb and flow system and the influence of the substrate.

\section{MATERIAL AND METHODS}

The experiment was conducted in Quintas da Fazendinha $\left(19^{\circ} 30^{\prime} 37.9^{\prime \prime} \mathrm{S} ; 44^{\circ} 05^{\prime} 31.9^{\prime \prime} \mathrm{W}\right)$ in the region of Matozinhos, central region of Minas Gerais, Brazil. The average altitude is $808 \mathrm{~m}$ in relation to sea level. The $e b b$ and flow system was characterized by wooden boxes leveled and waterproofed with black plastic with the following dimensions: $2.70 \mathrm{~m} \times 1.30 \mathrm{~m} \times 0.10 \mathrm{~m}$. At a height of $0.05 \mathrm{~m}$ at the edge of the box was placed an exit to return the nutrient solution to a reservoir restricting the capacity of the box to a volume of $175.5 \mathrm{~L}$.

The treatments consisted of 10 types of substrate with the following constitutions: (1) $60 \%$ sand $+40 \%$ coal powder; (2) $80 \%$ coconut fiber $+20 \%$ vermiculite; $(3) 80 \%$ sand $+20 \%$ coal powder; (4) $70 \%$ sand $+30 \%$ humus; (5) coconut fiber; (6) $70 \%$ sand $+30 \%$ vermiculite; (7) $80 \%$ sand $+20 \%$ vermiculite; (8) sand; (9) commercial substrate based on sphagno peat, expanded vermiculite, dolomitic limestone, agricultural gypsum and traces of NPK fertilizer; (10) 50\% sand $+30 \%$ humus $+20 \%$ vermiculite.

It was used average sand used in civil construction. Is was determinate the aparent density and volume retained by this material after pre-drying in sun obtaining the following results $1.55 \mathrm{~kg}$ $\mathrm{dm}^{-3}$ e $0.115 \mathrm{~L} \mathrm{dm}^{-3}$. The Carolina ${ }^{\circledR}$ commercial substrate had the following constitution: sphagno turf, expanded vermiculite, dolomitic limestone, agricultural plaster and NPK Fertilizer (traces), density: $145 \mathrm{~kg} \mathrm{~m}^{-3}$, water retention capacity (CRA), 55\%, maximum humidity: 50\%, without granulometric specification.

The vermiculite used contained the following characteristics: $\mathrm{pH}=7.0, \mathrm{CRA}=60 \%$, density $=80$ $\mathrm{kg} \mathrm{m}^{-3}$ without granulometric specification. According Catunda et al. (2016) [11] the fiber of Cocos nucifera $\mathrm{L}$. has density of $0.1657 \mathrm{~g} \mathrm{~cm}^{-3}$ and humidity around $66.26 \%$. The humus used had the following characteristics in percentages according to the manufacturer: total $\mathrm{N}=3.0 ; \mathrm{P}_{2} \mathrm{O}_{5}$ $=2.0 ; \mathrm{K}_{2} \mathrm{O}=6.0, \mathrm{MgO}=1.0, \mathrm{SO}_{3}=2.0$ and $\mathrm{Fe}=250 \mathrm{ppm}$, density $=1.25 \mathrm{~kg} \mathrm{~L}^{-1}$. 
Information on the physical and chemical characteristics of coal dust is scarce. In the present work, it was utilized data obtained by Tavares et al. (2010) [12]: granulometry $=4 \mathrm{~mm}$, wet density $=505 \mathrm{gL}^{-1}$; dry dems $=304 \mathrm{gL}^{-1}$; total porosity $=78 \%, \mathrm{CRA}=62 \%$ and $\mathrm{pH}=9.4$.

Seedlings of the cultivar Common taioba were produced by shoots treated against Fusarium spp., which were packed in plastic pots drilled with dimensions of $18 \mathrm{~cm}$ in diameter at the top, $12.2 \mathrm{~cm}$ in depth and $15 \mathrm{~cm}$ in height, making up volume of $2719.3 \mathrm{~cm}^{3}$ which were filled with the substrates tested. After bud bursting, they were transferred to the ebb and flow irrigation system.

The plots were composed of five pots for each treatment. The pots were spaced $10 \mathrm{~cm}$ apart, arranged in a randomized block design with four repetitions. A nutrient solution adapted from Furlani et al. (1999) [13] was used with the following constitution in ppm: $\mathrm{N}^{-\mathrm{NO}_{3}}=238.0 ; \mathrm{P}=$ $62 ; \mathrm{K}=426.0 ; \mathrm{Ca}=161.0 ; \mathrm{Mg}=24.0 ; \mathrm{S}=32.0 ; \mathrm{B}=0.3 ; \mathrm{Cu}=0.05 ; \mathrm{Fe}=5.0 ; \mathrm{Mn}=0.4 ; \mathrm{Mo}=$ 0.05 and $\mathrm{Zn}=0.3$.

The circulation of the nutrient solution in the system was adjusted after preliminary trials. From $6 \mathrm{am}$, the nutrient solution circulates for 30 minutes every 4 hours until $9 \mathrm{pm}$ and circulated again at 6 am the other day, with the same regime. In this way, the plants were sub irrigated by capillarity action with immersion of 30 to $33 \%$ of the volume of the pots [14]. This was possible, since in addition to the delimitation output of the nutrient solution volume, a drainage orifice of the nutrient solution was drilled into the bottom of the irrigation system to allow it to return to the reservoir. The drainage orifice has been dimensioned to provide an inlet flow of the nutrient solution greater than the outlet flow allowing flooding up to the $0.05 \mathrm{~m}$ box height limit. The nutrient solution was conducted with an electrical conductivity (EC) of $3.5 \mathrm{mS} / \mathrm{cm}$ in order to maintain the original nutrient content of the nutrient solution.

Immediately after harvest, which occurred 80 days after planting, the taioba plants were stored in thermal boxes and transported under refrigeration to the Food Conservation Laboratory of Federal University of São João del-Rei (UFSJ), Sete Lagoas, MG, where they were prepared and evaluated for their physico-chemical characteristics and bioactive compounds. Physical characteristics such as number of leaves, plant height, stem diameter and transverse and longitudinal leaf diameters were obtained through counts and direct measurements in the plant using a graduated ruler and digital caliper.

The total soluble solids content (TSSC) were determined by extracting the untreated and filtered leaves of the taioba in natura on the prism of the digital refractometer Reichert R2MINI [15]. To determine the total solids content, five grams of the in natura leaves were placed in crucibles submitted to $105^{\circ} \mathrm{C}$ in a sterilization oven and dried to a constant weight. The total solids content was calculated based on the difference between the initial and final masses [15].

The $\mathrm{pH}$ was determined using a Tekna T-1000 digital pHmeter by direct electrode immersion in the extract of the macerated and filtered in natura leaves [15]. In determining the titratable acidity (TA), about five grams of the leaves of the in natura sample were macerated, filtered and the extract obtained was diluted in $50 \mathrm{~mL}$ of distilled water and titrated with $0.01 \mathrm{~N} \mathrm{NaOH}$ solution, where the indicator used was phenolphthalein, according to the methodology described in AOAC (2012) [15].

For the determination of the total carotenoid content, the methodology proposed by RodriguezAmaya (2001) [16] was followed using in natura samples. After extraction, the total carotenoids were quantified in a Femto 700 spectrophotometer without $450 \mathrm{~nm}$ and the results were expressed in $\mu \mathrm{g}$ of total carotenoids per 100 grams of fresh sample. The spectrophotometric method of FolinCiocalteau, modified by Neves et al. (2009) [17], was used for the quantification of total phenolic compounds which were expressed in g EAG per $100 \mathrm{~g}$ dry sample.

The quantification of the total chlorophyll content was performed according to the methodology proposed by Silva et al. (2009) [18] where in natura samples were used. After extraction with acetone, the quantification was done in spectrophotometer (Femto 700S) at 652 $\mathrm{nm}$. The results were expressed in mg per $100 \mathrm{~g}$ fresh sample [19] After the verification of the assumptions by analysis of normality of the residues (Kolmogorov's test), homogeneity of variances (Lilliefors's test) and additivity of the blocks, analysis of variance (test F, p <0.05) was performed and, in case of significant effect, the mean test (Tukey $\mathrm{p}<0.05$ ) was performed. The analysis were performed with the software GENES [20]. For this work only the data of the first 
harvest were considered not being evaluated, therefore, data of subsequent harvests as it is common in the commercial production of taioba.

\section{RESULTS AND DISCUSSION}

It was observed (Table 1) that the diameter of the stem (ST) was significantly higher in plants grown with treatments 2 and 9 respectively coconut fiber with $20 \%$ vermiculite and commercial substrate Carolina ${ }^{\circledR}$. Regarding the number of leaves (NL), only the treatment 3 (sand $80 \%$; coal powder 20\%) differed statistically from the other treatments presenting a significantly lower result. According to Santos et al. (2010) [21] the number of leaves is a factor that can be influenced by the environment, so the environment, together with the genetic component of the plant, provides physiological changes. For lettuce, the number of leaves is very important, since it indicates adaptation of the genetic material to the environment and because it is related to commercialization [22], which may be valid for taioba.

Table 1. Taioba stem diameter (ST) and number of leaves (NL), in function of the treatments.

\begin{tabular}{lcc}
\hline \multirow{2}{*}{ Treatments } & \multicolumn{2}{c}{ Evaluated Characteristics } \\
\cline { 2 - 3 } & ST $(\mathrm{cm})$ & NL \\
\hline 1-Sand (60\%) + coal powder (40\%) & $2.05 \mathrm{bc}$ & $3.50 \mathrm{ab}$ \\
2-Coconut fiber (80\%) + vermiculite $(20 \%)$ & $3.00 \mathrm{a}$ & $4.33 \mathrm{ab}$ \\
3-Sand (80\%) + coal powder (20\%) & $1.79 \mathrm{bc}$ & $3.20 \mathrm{~b}$ \\
4-Sand (70\%) + humus (30\%) & $2.13 \mathrm{bc}$ & $4.10 \mathrm{ab}$ \\
5-Coconut fiber & $2.16 \mathrm{~b}$ & $4.33 \mathrm{ab}$ \\
6-Sand (70\%) + vermiculite (30\%) & $2.19 \mathrm{~b}$ & $4.43 \mathrm{a}$ \\
7-Sand (80\%) + vermiculite (20\%) & $1.96 \mathrm{bc}$ & $4.20 \mathrm{ab}$ \\
8-Sand & $1.50 \mathrm{c}$ & $3.50 \mathrm{ab}$ \\
9-Commercial substrate & $3.26 \mathrm{a}$ & $4.50 \mathrm{a}$ \\
10-Sand (50\%) + humus (30\%) + coal powder (20\%) & $2.26 \mathrm{~b}$ & $4.50 \mathrm{a}$ \\
\hline CV (\%) & 2.23 & 4.06 \\
\hline
\end{tabular}

Means followed by the same lower-case letters in columns and upper-case letters in rows do not differ according to the Tukey test at $5 \%$.

Longitudinal length of the leaf (LLL) and transverse length of the leaf (TLL) are characteristics that define the size and shape of the leaves. For vegetables whose leaves are the edible parts and therefore marketable, size they are important because define the classification and the commercial standard. It was observed that treatment 2 and treatment 9 were the ones that provided the optimization of these characteristics indicating marketable leaves (Table 2). The commercial substrate (treatment 9), has its constituent components that probably to potentially absorb nutrients from the nutrient solution, resulting in a better development of rhizomes of the taioba with consequent advanced results currently.

Specifically, sphagno peat, second, increases oxygenation and nutrient availability, has greater water retention, due to low temperature and promotes excellent root development [23], the same with treatment 2 ( $80 \%$ coconut fiber $+20 \%$ vermiculite). Coconut fiber is a substrate of excellent use for seedling production because it has good physical properties, long durability without changing physical characteristics [24]. The productivity gains are related to the plants with larger diameter and mass of leaves and stem, which is valid for hardwoods [25].

This feature combined with the larger ST, NL, LLL and TLL shows a robust and well-adapted plant with potential for growth and production. In summary, treatments 2 and 9 were those that optimized all these characteristics indicating the adaptation of taioba to the culture system. As was observed for the characteristics (LLL) and (TLL) (Table 2), the composition of the substrates referring to these treatments (Sphagno peat, expanded vermiculite, dolomitic limestone, agricultural gypsum, traces of NPK fertilizer and coconut fiber, favored the best development of the plant. 
Table 2. Longitudinal length of the leaf (LLL) and transverse length of the leaf (TLL) of taioba in function of the treatments.

\begin{tabular}{lcc}
\hline \multirow{2}{*}{ Treatments } & \multicolumn{2}{c}{ Evaluated Characteristics } \\
\cline { 2 - 3 } & LLL $(\mathrm{cm})$ & TLL $(\mathrm{cm})$ \\
\hline 1-Sand (60\%) + coal powder $(40 \%)$ & $14.73 \mathrm{bc}$ & $13.76 \mathrm{~cd}$ \\
2-Coconut fiber (80\%) + vermiculite $(20 \%)$ & $19.40 \mathrm{ab}$ & $22.76 \mathrm{ab}$ \\
3-Sand (80\%) + coal powder $(20 \%)$ & $15.53 \mathrm{bc}$ & $15.00 \mathrm{~cd}$ \\
4-Sand (70\%) + humus (30\%) & $16.86 \mathrm{abc}$ & $18.76 \mathrm{bcd}$ \\
5-Coconut fiber & $19.13 \mathrm{ab}$ & $20.53 \mathrm{abc}$ \\
6-Sand (70\%) + vermiculite (30\%) & $15.53 \mathrm{bc}$ & $14.89 \mathrm{~cd}$ \\
7-Sand (80\%) + vermiculite (20\%) & $14.60 \mathrm{bc}$ & $14.89 \mathrm{~cd}$ \\
8-Sand & $13.23 \mathrm{c}$ & $12.06 \mathrm{~d}$ \\
9-Commercial substrate & $21.53 \mathrm{a}$ & $26.46 \mathrm{a}$ \\
10-Sand (50\%) + humus (30\%) + coal powder (20\%) & $18.43 \mathrm{abc}$ & $20.08 \mathrm{abc}$ \\
\hline CV (\%) & 16.87 & 17.84 \\
\hline Myy
\end{tabular}

Means followed by the same lower-case letters in columns and upper-case letters in rows do not differ according to the Tukey test at $5 \%$.

Plant height (PH) and stem diameter (ST) indicate plant size. It was observed (Table 3) that for plant height $(\mathrm{PH})$ treatment 9 (commercial substrate) provided a significantly lower height than the other treatments.

Table 3. Plant height (PH) and fresh root mass (FRM) of taioba in function of the treatments.

\begin{tabular}{lcc}
\hline \multirow{2}{*}{ Treatments } & \multicolumn{2}{c}{ Evaluated Characteristics } \\
\cline { 2 - 3 } & PH $(\mathrm{cm})$ & FRM $(\mathrm{g})$ \\
\hline 1-Sand $(60 \%)+$ coal powder $(40 \%)$ & $25.08 \mathrm{~cd}$ & $18.00 \mathrm{~d}$ \\
2-Coconut fiber $(80 \%)+$ vermiculite $(20 \%)$ & $39.33 \mathrm{ab}$ & $53.96 \mathrm{~b}$ \\
3-Sand (80\%) + coal powder (20\%) & $26.60 \mathrm{~cd}$ & $40.97 \mathrm{bc}$ \\
4-Sand (70\%) +humus (30\%) & $32.21 \mathrm{abc}$ & $21.19 \mathrm{~d}$ \\
5-Coconut fiber & $32.93 \mathrm{abc}$ & $43.31 \mathrm{bc}$ \\
6- Sand (70\%) + vermiculite (30\%) & $28.54 \mathrm{bcd}$ & $31.39 \mathrm{~cd}$ \\
7-Sand (80\%) + vermiculite (20\%) & $26.01 \mathrm{~cd}$ & $29.99 \mathrm{~cd}$ \\
8-Sand & $40.44 \mathrm{a}$ & $19.48 \mathrm{~d}$ \\
9-Commercial substrate & $19.63 \mathrm{~d}$ & $88.99 \mathrm{a}$ \\
10-Sand (50\%) + humus (30\%) + coal powder (20\%) & $30.46 \mathrm{abcd}$ & $25.64 \mathrm{~d}$ \\
\hline CV $(\%)$ & 30.12 & 14.07 \\
\hline
\end{tabular}

Means followed by the same lower-case letters in columns and upper-case letters in rows do not differ according to the Tukey test at $5 \%$.

For the results of fresh root mass (FRM), dry root mass (DRM), fresh plant mass (FPM) and mass dry plant (MDP), it was also observed that the best results were obtained with treatment 9 These results indicate good response of the plants to the ebb and flow production system and specifically to the substrate. (Tables 3,4 and 5).

Table 4. Dry root mass (DRM) and Fresh plant mass (FPM) of taioba in function of the treatments.

\begin{tabular}{lcc}
\hline \multirow{2}{*}{ Treatments } & \multicolumn{2}{c}{ Evaluated Characteristics } \\
\cline { 2 - 3 } & DRM $(\mathrm{g})$ & FPM $(\mathrm{g})$ \\
\hline 1-Sand (60\%) + coal powder (40\%) & $3.40 \mathrm{bcd}$ & $104.42 \mathrm{~cd}$ \\
2-Coconut fiber (80\%) + vermiculite (20\%) & $4.85 \mathrm{~b}$ & $148.53 \mathrm{~b}$ \\
3-Sand (80\%) + coal powder (20\%) & $4.13 \mathrm{bc}$ & $47.63 \mathrm{f}$ \\
4-Sand (70\%) + humus (30\%) & $3.36 \mathrm{bcd}$ & $141.11 \mathrm{~b}$ \\
5-Coconut fiber & $3.53 \mathrm{bcd}$ & $45.40 \mathrm{f}$ \\
6-Sand (70\%) + vermiculite (30\%) & $2.29 \mathrm{~d}$ & $119.42 \mathrm{c}$
\end{tabular}




\begin{tabular}{lcc} 
7-Sand $(80 \%)+$ vermiculite $(20 \%)$ & $3.51 \mathrm{bcd}$ & $88.86 \mathrm{~d}$ \\
8-Sand & $2.64 \mathrm{~cd}$ & $66.86 \mathrm{e}$ \\
9-Commercial substrate & $7.17 \mathrm{a}$ & $308.55 \mathrm{a}$ \\
10-Sand (50\%) + humus (30\%) + coal powder (20\%) & $2.80 \mathrm{~cd}$ & $115.83 \mathrm{c}$ \\
\hline CV $(\%)$ & 3.77 & 5.22 \\
\hline
\end{tabular}

Means followed by the same lower-case letters in columns and upper-case letters in rows do not differ according to the Tukey test at $5 \%$.

Table 5. Mass dry plant (MDP) and titratable acidity of fresh sample (TA) in function of the treatments.

\begin{tabular}{lcc}
\hline \multirow{2}{*}{ Treatments } & \multicolumn{2}{c}{ Evaluated Characteristics } \\
\cline { 2 - 3 } & MDP $(\mathrm{g})$ & TA (mg citric acid/100 g) \\
\hline 1-Sand (60\%) + coal powder (40\%) & $11.32 \mathrm{~b}$ & $0.08 \mathrm{a}^{*}$ \\
2-Coconut fiber (80\%) + vermiculite $(20 \%)$ & $11.22 \mathrm{~b}$ & $0.08 \mathrm{a}$ \\
3-Sand (80\%) + coal powder (20\%) & $5.03 \mathrm{bc}$ & $0.07 \mathrm{a}$ \\
4-Sand (70\%) + humus (30\%) & $7.91 \mathrm{bc}$ & $0.10 \mathrm{a}$ \\
5-Coconut fiber & $2.11 \mathrm{c}$ & $0.09 \mathrm{a}$ \\
6-Sand (70\%) + vermiculite (30\%) & $10.82 \mathrm{~b}$ & $0.09 \mathrm{a}$ \\
7-Sand (80\%) + vermiculite (20\%) & $7.91 \mathrm{bc}$ & $0.08 \mathrm{a}$ \\
8-Sand & $6.78 \mathrm{bc}$ & $0.05 \mathrm{a}$ \\
9-Commercial substrate & $23.59 \mathrm{a}$ & $0.11 \mathrm{a}$ \\
10-Sand (50\%) + humus (30\%) + coal powder (20\%) & $12.81 \mathrm{~b}$ & $0.09 \mathrm{a}$ \\
\hline CV $(\%)$ & 28.60 & 24.11
\end{tabular}

Means followed by the same lower-case letters in columns and upper-case letters in rows do not differ according to the Tukey test at $5 \%$.

For Titratable Acidity (TA), Total Soluble Solids (TSS), pH, Carotenoids Total (CT), Phenolic Compounds Total (FCT) and Chlorophyll (C) no significant differences were observed (Tables 5,6 and 7).

Table 6. Total Soluble Solids (TSS) and pH in function of the treatments.

\begin{tabular}{lcc}
\hline \multirow{2}{*}{ Treatments } & \multicolumn{2}{c}{ Evaluated Characteristics } \\
\cline { 2 - 3 } & TSS (Brix) & pH \\
\hline 1-Sand (60\%) + coal powder (40\%) & $4.95 \mathrm{a}^{*}$ & $6.66 \mathrm{a}^{*}$ \\
2-Coconut fiber (80\%) + vermiculite (20\%) & $4.55 \mathrm{a}$ & $6.62 \mathrm{a}$ \\
3-Sand (80\%) + coal powder (20\%) & $4.41 \mathrm{a}$ & $6.60 \mathrm{a}$ \\
4-Sand (70\%) + humus (30\%) & $5.40 \mathrm{a}$ & $6.29 \mathrm{a}$ \\
5-Coconut fiber & $4.02 \mathrm{a}$ & $6.28 \mathrm{a}$ \\
6-Sand (70\%) + vermiculite (30\%) & $4.32 \mathrm{a}$ & $6.21 \mathrm{a}$ \\
7-Sand (80\%) +vermiculite (20\%) & $5.33 \mathrm{a}$ & $6.17 \mathrm{a}$ \\
8-Sand & $4.30 \mathrm{a}$ & $6.15 \mathrm{a}$ \\
9-Commercial substrate & $5.10 \mathrm{a}$ & $6.11 \mathrm{a}$ \\
10-Sand (50\%) + humus (30\%) + coal powder (20\%) & $4.26 \mathrm{a}$ & $6.10 \mathrm{a}$ \\
\hline CV (\%) & 13.80 & 5.08 \\
\hline
\end{tabular}

Means followed by the same lower-case letters in columns and upper-case letters in rows do not differ according to the Tukey test at $5 \%$.

In the case of lettuce, chicory and arugula, Arbos et al. (2010) [9] found significant differences in the content of phenolic compounds of these vegetables between organic and conventional cultivation $(0.108,0.092,0.128$ and $0.091,0.081,0.090 \mathrm{~g}$ EAG), respectively. These values of phenolic compounds were higher than those found for taioba. In terms of total carotenoids (CT), although significant differences were found, this was only due to the substrate 6 (sand $70 \%+$ vermiculite 30\%), which produced lower total carotenoid content (Table 7). 
Table 7. Carotenoids total - ug total carotenoid/100g fresh sample (CT), phenolic compounds total - $g$ GAE/l00g dry sample (FCT) and chlorophyll - $\mathrm{mg} / \mathrm{l00g}$ fresh sample (C) in function of the treatments.

\begin{tabular}{lccc}
\hline \multirow{2}{*}{ Treatment } & \multicolumn{3}{c}{ Evaluated characteristics } \\
\cline { 2 - 4 } & CT & FCT & C \\
\hline 1-Sand (60\%) + coal powder (40\%) & $44107,73 \mathrm{ab}$ & $0.05 \mathrm{a}^{*}$ & $310.44 \mathrm{a}^{*}$ \\
2-Coconut fiber (80\%) + vermiculite $(20 \%)$ & $34588,83 \mathrm{ab}$ & $0.06 \mathrm{a}$ & $273.94 \mathrm{a}$ \\
3-Sand (80\%) + coal powder (20\%) & $47924,15 \mathrm{ab}$ & $0.09 \mathrm{a}$ & $331.51 \mathrm{a}$ \\
4-Sand (70\%) + humus (30\%) & $43790,27 \mathrm{ab}$ & $0.08 \mathrm{a}$ & $285.25 \mathrm{a}$ \\
5-Coconut fiber & $56173,84 \mathrm{a}$ & $0.08 \mathrm{a}$ & $283.18 \mathrm{a}$ \\
6-Sand (70\%) + vermiculite (30\%) & $26830,67 \mathrm{~b}$ & $0.05 \mathrm{a}$ & $274.13 \mathrm{a}$ \\
7-Sand (80\%) + vermiculite (20\%) & $46785,22 \mathrm{ab}$ & $0.07 \mathrm{a}$ & $277.98 \mathrm{a}$ \\
8-Sand & $39767,50 \mathrm{ab}$ & $0.10 \mathrm{a}$ & $269.09 \mathrm{a}$ \\
9-Commercial substrate & $48617,84 \mathrm{ab}$ & $0.08 \mathrm{a}$ & $320.14 \mathrm{a}$ \\
10-Sand (50\%) + humus (30\%) + coal powder (20\%) & $52469,96 \mathrm{ab}$ & $0.08 \mathrm{a}$ & $347.25 \mathrm{a}$ \\
\hline CV (\%) & 21.07 & 29.62 & 28.58 \\
\hline
\end{tabular}

Means followed by the same lower-case letters in columns and upper-case letters in rows do not differ according to the Tukey test at $5 \%$.

For the different treatments, taioba presented $\mathrm{pH}$ values lower than 7 (Table 6). The $\mathrm{pH}$ of this vegetable is similar to that of Caruru (Amaranthus viridis), 6.72 and peixinho (Stachislanata), 6.11 according to a study carried out by Viana (2014) [26] on fresh samples. There are still few studies showing values of titratable acidity, total soluble solids and $\mathrm{pH}$ of this herbaceous in the literature and with different substrates studied in this situation.

According to Fagundes et al. (2007) [27] the decrease of chlorophyll due to nitrogen deficiency results in the yellowing of leaves and indicates foliar senescence which was not observed in the present study.

The significant differences observed in the agronomic characteristics of taioba, show superiority of the treatments 2 and 9 respectively coconut fiber with $20 \%$ vermiculite and commercial substrate Carolina ${ }^{\circledR}$. Probably the characteristics of these substrates have provided better root development. In order to evaluate the production of strawberry varieties in different production systems and environment technology, including coconut fiber and charcoal rice husk as pure substrates [28] observed that the best hydroponic production system in all environments was which contained the coconut fiber. On the other hand, the use of the pure commercial substrate Carolina ${ }^{\circledR}$ probably showed results significantly superior to the others due to the characteristics of its components. Although the coal powder has adequate characteristics, the high value of its $\mathrm{pH}$ (9.4) may have had a negative influence on the evaluated characteristics.

\section{CONCLUSION}

It that cultivation of taioba in the hydroponic ebb and flow system has technical feasibility. The substrate has influence in the technical feasibility.

\section{REFERENCES}

1. Santos WM, Seabra Junior S, Nolasco F, Campos RAS, Silva MB, Rodrigues LFOS. Produção de mudas de taioba em função do tipo e seccionamento de rizomas. Científica. 2013;42(1):74-79, doi: $10.15361 / 1984-5529.2014 \mathrm{v} 42 \mathrm{n} 1 \mathrm{p} 74-79$

2. Calixto MLC, Correia RR, Gomes ACC, Justo G, Coelho MGP, Sakuragui CM, Kuster RM, Sabino KCC. In vitro Antileukemic activity of Xanthosoma sagittifolium (Taioba) leaf extract. Evid Based Complement Alternat Med. 2015;2015:384267, doi: 10.1155/2015/384267.

3. Almeida EFA, Lessa MA, Paiva PDO, Carvalho LMC, Landgraf PRC, Silva EC. Produção de copo-deleite em sistema hidropônico ebb and flood. Rev Plasticultura. 2014:22-24.

4. Ferrarezi RS, Weaver GM, Van Iersel MW, Testezlaf R. Subirrigation: Historical overview, challenges, and future prospects. HortTechnol. 2015a;25(3):262-276, doi:10.21273/HORTTECH.25.3.262. 
5. Ferrarezi RS, Weaver GM, Van Iersel MW, Testezlaf R. Monitoring and controlling ebb-and-flow subirrigation with soil moisture sensors. HortSci. 2015b;50(3):447-453.

6. Ferrarezi RS, Weaver GM, Van Iersel MW, Testezlaf R. Subirrigation automated by capacitance sensors for salvia production. Hortic Bras. 2014;32(3):314-322, doi: 10.1590/S0102-05362014000300013

7. Ensinas SC, Maekawa Junior MT, Ensinas BC. Desenvolvimento de mudas de rúcula em diferentes combinações de substrato. Rev Cient Eletr Agron. 2011;18(1):1-7.

8. Globo-Neto L, Lopes NP. Plantas medicinais: fatores de influência no conteúdo de metabólitos secundários. Química Nova 2007;30(20):374-381.

9. Arbos KA, Freitas RJS, Stertz SC, Dorna, MF. Atividade antioxidante e teor de fenólicos totais em hortaliças orgânicas e convencionais. Ci Tecnol Alim. 2010;30(2):501-506.

10. Vence LB. Disponibilidad de agua-aire em sustratos para plantas. Ciencia Del Suelo. 2008;26(2):105114.

11. Catunda T, Amazonas M, Matos T. Potencial tecnológico da fibra de coco como matéria prima alternativa ao desenvolvimento de produtos sustentáveis. Educ Amb Ação. 2016;15(57).

12. Tavares TR, Rosa JQS, Balbino MPA, Farias GG. Composto orgânico e pó de carvão vegetal: o enxofre elementar para redução do pH. In XXXIII Congresso Brasileiro de Ciência do Solo; 2010 July 31-Aug 05; Uberlândia, MG. p. 1-4.

13. Furlani PR, Silveira LCP, Bolonhezi D, Faquim V. Cultivo hidropônico de plantas. Campinas: Instituto Agronômico de Campinas; 1999. 52 p. (Boletim técnico, 180).

14. Barreto CVG, Ferrarezi RS, Testezlaf R, Arruda FB. Growth and physiological responses of Rangpur lime seedlings irrigated by a prototype subirrigation tray. HortSci. 2015;50(1):123-129.

15. AOAC. Association of Official Analytical Chemistry. Official methods of 255 analysis of the Association of Official Analytical Chemistry. Gaitherburg; 2012. 3000 p.

16. Rodriguez-Amaya DB. A guide to carotenoid analysis in foods. Washington; 2001. 64 p.

17. Neves LC, Alencar SM, Carpes ST. Determinação da Atividade antioxidante e do teor de compostos fenólicos e flavonoides totais em amostras de pólen apícola de Apis mellifera. Braz J Food Technol. 2009;7(1):106 -110.

18. Silva EP, Vilas Boas EVB, Rodrigues LJ, Siqueira HH. Caracterização física, química e fisiológica de gabiroba (Campomanesia pubescens) durante o desenvolvimento. Rev Ci Tecnol Alimentos. 2009;29(4):803-809.

19. Engel VL, Poggiani F. Estudo da concentração de clorofila nas folhas e no espectro de absorção de luz em função do sombreamento em mudas de quatro espécies florestais nativas. Rev Bras Fisiol Veg. 1991;3(1):39-45.

20. Cruz CD. GENES A software package for analysis in experimental statistics and quantitative genetics. Acta Scient Agron. 2013;35(3):271-276.

21. Santos LL, Seabra Junior S, Nunes, MCM. Luminosidade, temperatura do ar e do solo em ambientes de cultivo protegido. Rev Ci Agro-Ambientais. 2010;8(1):83-93.

22. Diamante MS, Seabra Junior S, Inagaki AM, Silva MB, Dallacort R. Produção e resistência ao pendoamento de alfaces tipo lisa cultivadas sob diferentes ambientes. Rev Ci Agron. 2013;4(1):133140.

23. Zandonad DB, Santos MP, Medici LO, Silva J. Ação da matéria orgânica e suas frações sobre a fisiologia de hortaliças. Hortic Bras. 2014;32(1):14-20, doi: 10.1590/S0102-05362014000100003

24. Alexandre RS, Wagner Júnior A, Negreiros JRS, Bruckner CH. Estádio de maturação dos frutos e substratos na germinação de sementes e desenvolvimento inicial de plântulas de jabuticabeira. Rev Bras Agroci. 2006;12(2): 227-230.

25. Luz JMQ, Oliveira G, Queiroz AA, Carreon R. Aplicação foliar de fertilizantes organominerais em cultura de alface. Hortic Bras. 2010;28(3):373-377.

26. Viana MMS, Carlos LA, Silva EC, Pereira SMF, Oliveira DB, Assis MLV. Composição fitoquímica e potencial antioxidante de hortaliças não convencionais. Hortic Bras. 2014;32(4):504-509, doi: 10.1590/S0102-053620150000400016

27. Fagundes JD, Santiago G, Mello AM, Bellé RA, Streck NA. Crescimento, desenvolvimento e retardamento da senescência foliar em girassol de vaso (Helianthusannuus L.): fontes e doses de nitrogênio. Ci Rural. 2007;37(4):987-993.

28. Costa E, Leal PM. Avaliação de variedades de morangueiro em sistemas hidropônicos sob casa de vegetação. Rev Bras Frutic. 2008;30(2):425-430. 